\title{
ALC パネルの内部応力に関する EXAMINATION ON THE INTERNAL 検討 STRESS IN ALC PANEL
}

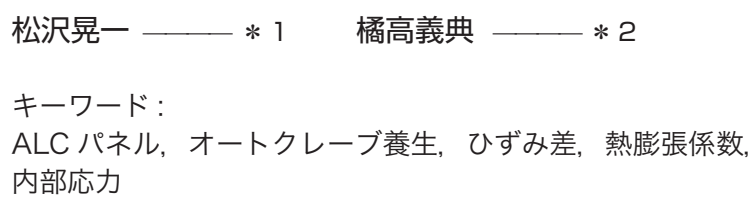

Keywords:

ALC panel, Autoclave cure, Strain difference, Coefficient of the thermal expansion, Internal stress

\section{Koichi MATSUZAWA — $* 1 \quad$ Yoshinori KITSUTAKA $-* 2$}

ALC panels become the building members with necessary strength and durability by the autoclave cure. Autoclave cure of ALC takes approximately $10 \mathrm{~h}$ under the temperature of $180^{\circ} \mathrm{C}$ and saturated steam pressure of $1 \mathrm{MPa}$. It is thought that strain difference between ALC and reinforcing bar, as a result of temperature change, causes the internal stress in ALC panels. This study was conducted to clarify the existence of the internal stress in ALC panels.

\section{1. はじめに}

ALC パネルの製造ならびに品質の概要は JIS A 5416 軽量気泡コ ンクリートパネルに規定されている。ALC パネルは, 型枠に補強筋 を配置し, 主原料であるセメント, 石灰質原料, 硅酸質原料, そし て,アルミ粉末などの発泡剂を練り混ぜたスラリーを型枠に投入し, 発泡した半硬化状態のグリーンケーキをピアノ線で所定の厚さに切 断した後, オートクレーブ養生を経て必要強度および耐久性を備え たパネルとなる。その後, それぞれの用途に応じた目地形状の加工, 寸法調整がなされ，ALCパネルとして出荷される。

$\mathrm{ALC}$ のオートクレーブ養生は, 温度 $180^{\circ} \mathrm{C}$, 圧力 $1 \mathrm{MPa}$ 程度の飽 和水蒸気下で約 10 時間の養生を施すもので, 硅酸カルシウム水和物 であるトバモライトの生成を目的として行われる, ALCの製造には 必要不可欠な工程である。本養生下では，グリーンケーキおよび内 部に埋設される補強筋が高温となるために膨張する。そして, 両者 が膨張した状態で硬化および一体化する。オートクレーブ養生が終 了すると, ALC パネルは常温まで徐々に冷却されて収縮する。その 際, ALC の熱膨張係数が約 $7 \times 10^{-6} /{ }^{\circ} \mathrm{C}^{1)}$ ，また，補強筋である鉄の 熱膨張係数が約 $10 \times 10^{-6} /{ }^{\circ} \mathrm{C}$ であることから, $\mathrm{ALC}$ パネルが冷却され ると, $1^{\circ} \mathrm{C}$ の温度変化に際し, ALC と補強筋には約 $3 \times 10^{-6}$ のひずみ

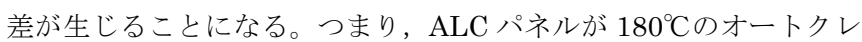
ーブ養生後に $20^{\circ} \mathrm{C}$ 常温まで泠却されると, 温度は $160^{\circ} \mathrm{C}$ 低下寸る ため, ALC と補強筋には約 $480 \times 10^{-6}$ のひずみ差が生じる。ALC と 補強筋は付着により一体化しているので, 両者は各々の収縮を相互 に妨げるように働き, 補強筋には引張ひずみを発生させる応力, そ して，ALCには圧縮ひずみを発生させる応力が作用すると思われる。
このように，冷却後の ALC パネル内部には，ALC と補強筋の熱膨 張係数の違いにより応力（本研究では, 内部応力）が作用している 可能性がある。

著者らは, 過去 ${ }^{2)}$ に ALC 単体の引張試験によるひび割れ発生時の ひずみの測定，そして，ALC パネルの曲げ試験による曲げひび割れ 発生時におけるパネルの引張縁のひずみの測定を行った。その結果， ALC 単体でのひずみが $292 \times 10^{-6}$ であるのに対し, ALC パネルの引 張縁のひずみは $579 \times 10^{-6}$ となり，両者には約 2 倍の差が生じてい た。試験に用いた ALC の製造ロットや, 試験時の載荷方法などの条 件が異なるものの，材料自体のひび割れ発生ひずみに 2 倍もの差が でるとは考えにくい。

この差は, オートクレーブ養生後の泠却時に, ALC と比較して収 縮の大きい補強筋の影響により, ALC に潜在的に圧縮応力が生じる ことで, 圧縮ひずみが発生していることが考えられる。つまり, ALC パネルの曲げひび割れ発生時の引張ひずみが ALC 単体に比べて大 きくなっているのは，潜在的に生じている圧縮ひずみが，見かけの 引張ひずみとして加算されたものと推察される。しかし，ALC パネ ル内に潜在的に発生する内部応力に関する詳細な報告はなされてお

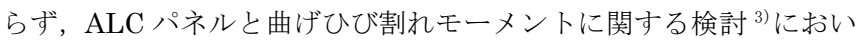
て, ALC パネル内にプレストレスが発生しているとの考察が述べら れているにとじまっている。

そこで, 本研究では, ALC 母材, 配筋量, 補強筋径が異なる ALC パネルを用いて, ALC 母材および母材内の補強筋に生じているひず みを測定することにより，ALC パネル内に生じていると思われる内 部応力に関する検討を行った。

\footnotetext{
首都大学東京大学院都市環境科学研究科建築学域 助教 - 修士 (工学) (T192-0397 八王子市南大沢 1-1)

2 首都大学東京大学院都市環境科学研究科建築学域 教授・工博
}

1 Assist. Prof., Dept. of Architecture and Building Engineering, Graduate School of Urban Environmental Sciences, Tokyo Metropolitan Univ., M. Eng.

Prof., Dept. of Architecture and Building Engineering, Graduate School of Urban Environmental Sciences, Tokyo Metropolitan Univ., Dr. Eng. 


\section{2. 実験概要}

\section{1 ALC パネル概要}

表 1 に試験に用いた ALC パネル一覧, 図 1 に ALC パネルの配筋 状況およびひずみゲージ（以下，ゲージ）の貼付け位置を示す。こ こに示寸配筋位置は, 実際の墨出し位置から計測した值となってい る。 ALC パネルは，母材が異なる 4 種類，補強筋径が $5,7 \mathrm{~mm}$ の 2 種類, $\mathrm{ALC}$ パネルの引張側の配筋量が $3,4,7$ 本の 3 種類とし, それらの組合せにより合計 6 種類について検討を行った。

なお，本研究に用いた ALC パネルは，製造会社により若干の差 異はあるものの, 密度が $500 \mathrm{~kg} / \mathrm{m}^{3}$ 程度, 圧縮強度が $5 \mathrm{~N} / \mathrm{mm}^{2}$ 程度 の，一般に市場に流通している JIS A 5416 に適合する ALC パネル である。

\section{2 ひずみ測定方法}

ひずみの測定は, ALC パネルの長辺方向に配置された引張側の主 筋と, そのかぶり部分の ALCについて行うこととした。そのため, それぞれのひずみを測定するために, 表 1 に示す ALC パネルにつ いて主筋ひずみ測定用，そして，ALCひずみ測定用としてそれぞれ 1 枚ずつ用いた。

まず，引張側が上面になるように ALC パネルを平置きして鉄筋 探査を行い，補強筋位置に墨出しを行った（写真 1$)$ 。

表 1 ALC パネルー覧

\begin{tabular}{c|c|c|c|c}
\hline $\begin{array}{c}\text { パネル } \\
\text { No. }\end{array}$ & 母材 & $\begin{array}{c}\text { 補強笳径 } \\
(\mathrm{mm})\end{array}$ & $\begin{array}{c}\text { 引張側配筋量 } \\
(\text { 本 })\end{array}$ & $\begin{array}{c}\text { 寸法 } \\
(\mathrm{mm})\end{array}$ \\
\hline 1 & $\mathrm{~A}$ & 5 & 3 & $100 \times 600 \times 2700$ \\
\hline 2 & $\mathrm{~A}$ & 5 & 7 & $100 \times 600 \times 2700$ \\
\hline 3 & $\mathrm{~A}$ & 7 & 7 & $100 \times 600 \times 2700$ \\
\hline 4 & $\mathrm{~B}$ & 5 & 3 & $100 \times 600 \times 2700$ \\
\hline 5 & $\mathrm{C}$ & 5 & 3 & $100 \times 600 \times 2990$ \\
\hline 6 & $\mathrm{D}$ & 5 & 4 & $100 \times 600 \times 3000$ \\
\hline
\end{tabular}

- - 補強筋 ロひずみゲージ マブ゙ージ近傍切り込み位置 $\mathbf{\nabla}$ 横筋近傍切り込み位置
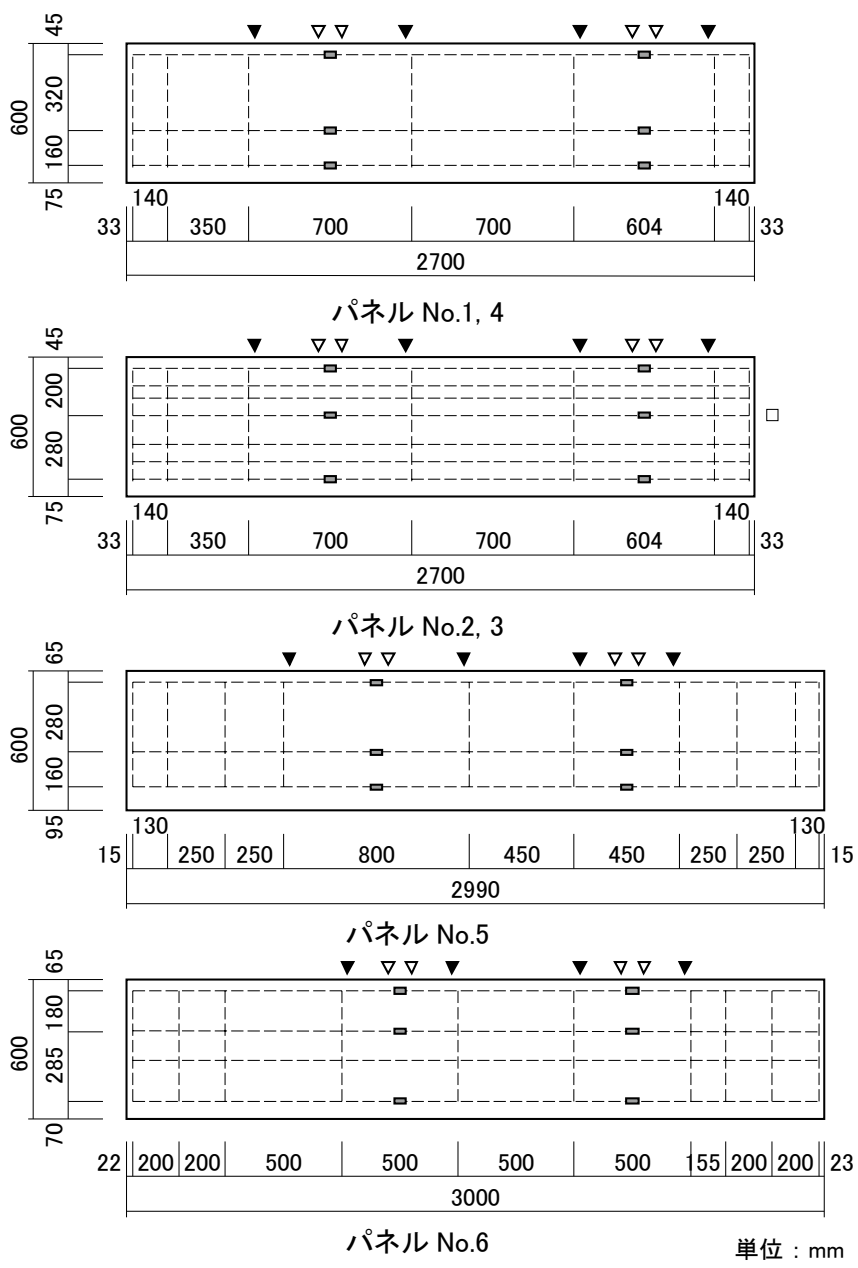

図 1 ALC パネルの配筋状況およびひずみゲージ貼付け位置

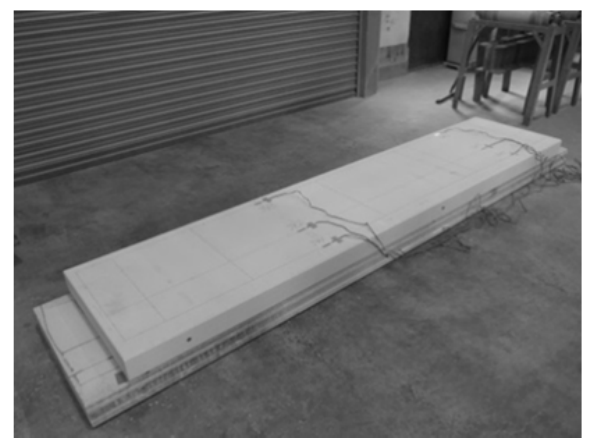

写真 1 ALCパネル

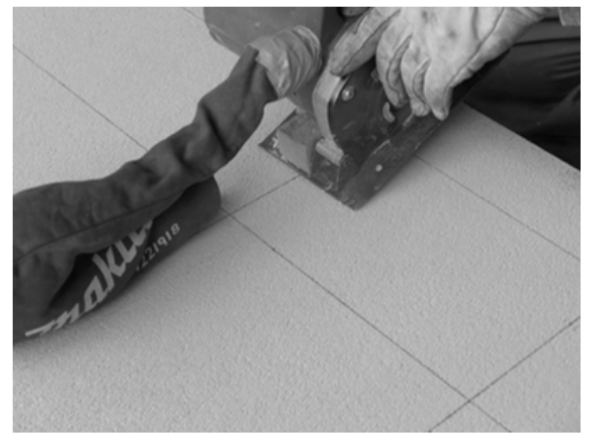

写真 4 ALC パネルの切断状況

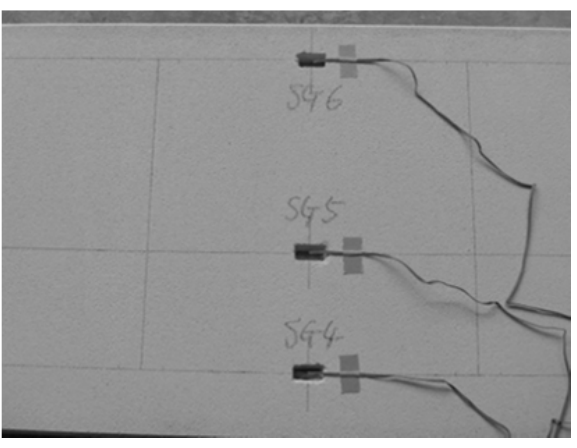

写真 2 主筋へのゲージ貼付け状況

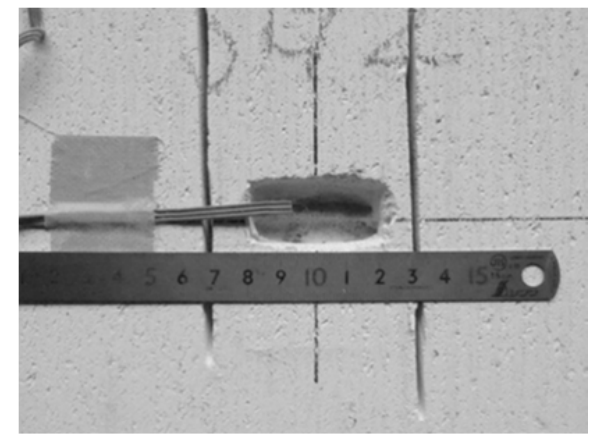

写真 5 切断後の主筋

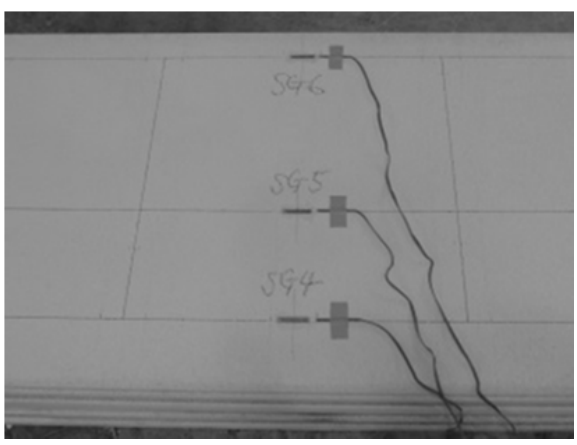

写真 3 パネル表面へのゲージ貼付け状況

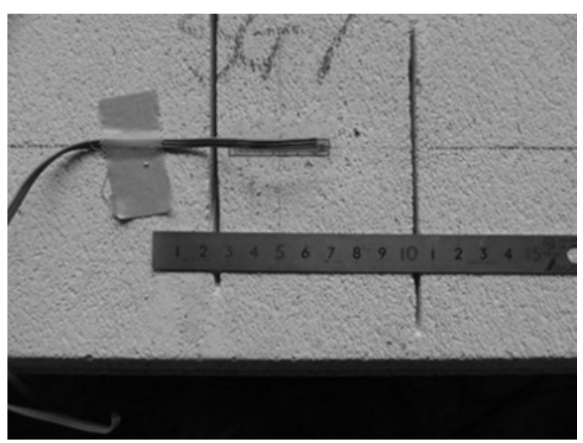

写真 6 切断後のパネル表面 
次に, ゲージと, その両側の ALC パネルの短辺方向に配置され た横筋との距離が同一となるように，その中心にゲージを貼り付け た。なお，主筋のひずみ測定には検長 $1 \mathrm{~mm}, \mathrm{ALC}$ のひずみ測定に は検長 $30 \mathrm{~mm}$ のゲージを用いた。測定箇所は，それぞれの ALC パ ネルにつき 6 箇所である (図 1 )。

主筋ひずみを測定した ALC パネルについては，ゲージ貼付け箇 所の周辺部 (ゲージ中心から主筋方向 $20 \mathrm{~mm}$, 横筋方向 $10 \mathrm{~mm}$ 程度) のALC を, 主筋を傷つけないように削り出し, 主筋に付着してい る粉などを除去した後にゲージを貼り付けた（写真 2 )。また, ALC ひずみを測定した ALC パネルについては，ゲージ貼付け箇所の凹 凸を平滑にした後にゲージを貼り付けた（写真 3）。

$\mathrm{ALC}$ パネルの切断にはハンドスキルソーを用い（写真 4), ゲー ジ中心から左右 $30 \sim 50 \mathrm{~mm}$ の位置（以下，ゲージ近傍）に，引張側 の主筋を切断するように切り込みを入れた（写真 5 , 写真 6 )。その 際, 主筋切断直前に測定したひずみと, 切断後にひずみの変化が落 ち着いたのを確認したときに測定したひずみとの差を, 内部応力に よって作用しているひずみとした。

また, 本研究では, 一部の ALC パネルについて, 主筋と ALC と の付着の影響をみることとした。これは，ゲージ近傍で主筋を切断 する前に, 横筋から $30 \mathrm{~mm}$ 内側の部分（以下，横筋近傍）の主筋を 切断し, 横筋による拘束がない状態におけるひずみ恋化を測定した ものである。

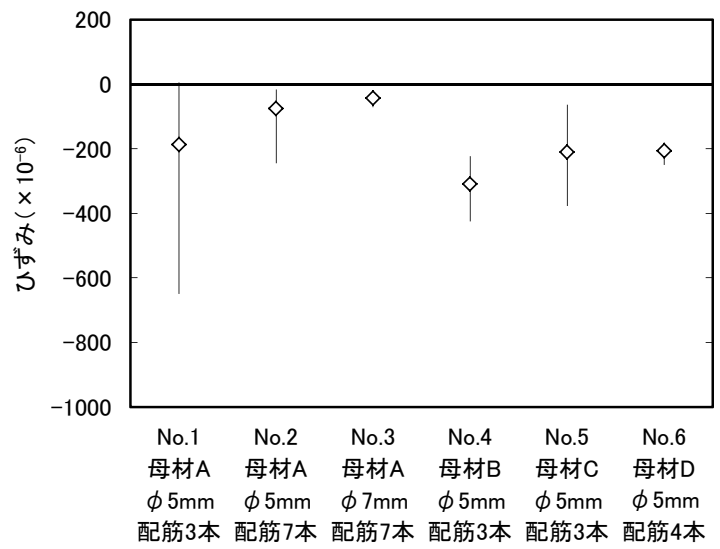

(a) 横筋近傍切断時

\section{3. 実験結果および考察}

\section{1 ALC パネル内部の主筋ひずみ}

図 2 に ALC パネル内部の主筋ひずみ測定結果を示す。なお, 図 中には測定された值の範囲を縦線，平均值をつで示してある。測定 箇所によってばらつきがあるものもあるが，主筋を切断するように $\mathrm{ALC}$ パネルに切り込みを入れることによって, 主筋には圧縮ひずみ が発生しているのがわかる。これは, ALC パネル内の主筋には潜在 的に引張応力が作用していることを示している。また，ゲージ近傍 (図 2(b)) と比較して, 横筋近傍（図 2(a)) で主筋を切断した際 のひずみが明らかに小さい。ALC と主筋には十分な付着力が働いて いるため, 横筋近傍で主筋を切断しても, 主筋のひずみ変化は小さ かったと判断できる。なお，横筋近傍とゲージ近傍の主筋を切断し た際のひずみ差は $300 \times 10^{-6} \sim 400 \times 10^{-6}$ 程度であった。

ゲージ近傍切断時における主筋のひずみ測定結果（図 $2(\mathrm{~b})$ ) に関 しては，同一母材で配筋量および補強筋径が異なる No.1，2，3 に ついて比較した場合, No.1 と比較して配筋量が多いNo.2 で $100 \times$ $10^{-6}$ 程度圧縮ひずみが小さい。そして, No.2 と比較して補強筋径が 大きい No.3でも $100 \times 10^{-6}$ 程度圧縮ひずみが小さくなった。また, 配筋量および補強筋径が同じで，母材が異なる No.1，4，5 を比較 した場合，ひずみ差は $100 \times 10^{-6}$ 程度の範囲であった。なお，補強 筋径が $5 \mathrm{~mm}$ で配筋量が 3 本の No.1，4，5 と，4 本の No.6 を比較 すると, No.6 の圧縮ひずみが小さくなる傾向にあった。

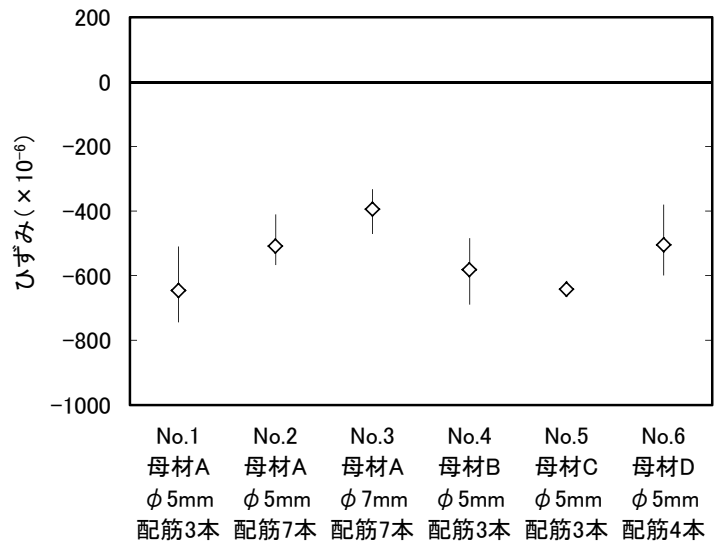

(b) ゲージ近傍切断時

図 2 主筋ひずみ測定結果

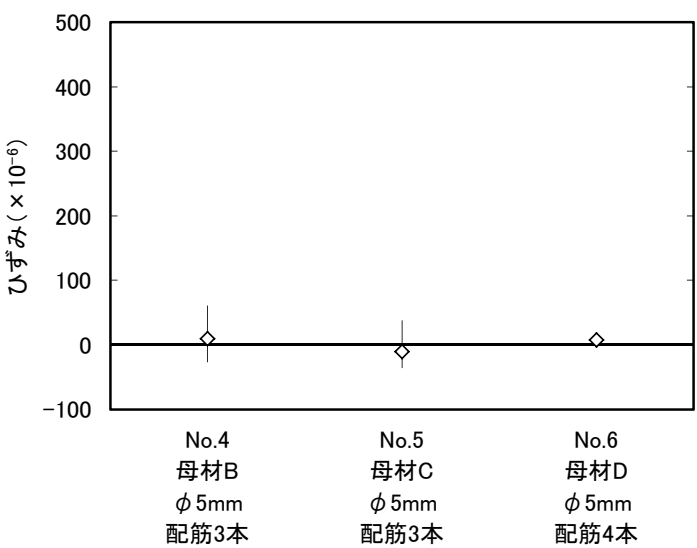

(a) 横筋近傍切断時

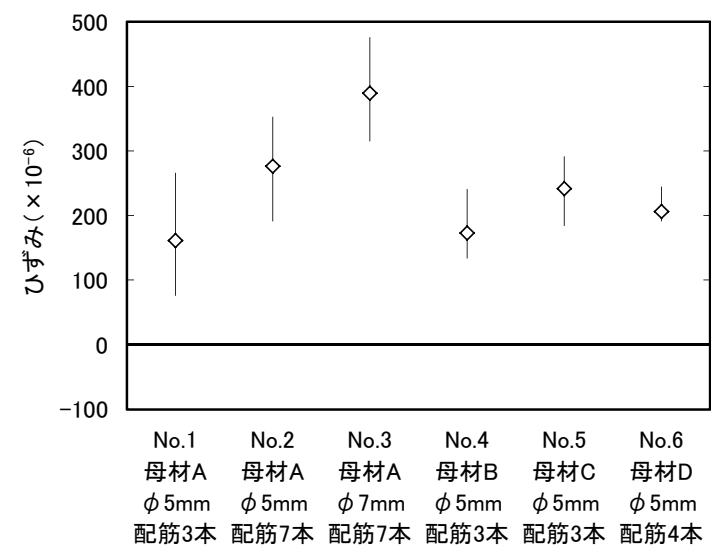

(b) ゲージ近傍切断時

図 3 ALC ひずみ測定結果 
母材である ALC の性状や, 補強筋に使用されている防錆剂の違 いなどにより, ALC と補強筋との付着性状も異なることが考えられ るが, 本研究の範囲内では, 配筋量が多くなると, そして, 補強筋 径が大きくなると圧縮ひずみが小さくなる結果となった。なお, 測 定されたひずみは $400 \times 10^{-6} \sim 700 \times 10^{-6}$ の範囲であった。

ところで, ALC パネルの構造設計に用いられる補強筋の許容応力 度は長期, 短期でそれぞれ $120 \mathrm{~N} / \mathrm{mm}^{2}, 180 \mathrm{~N} / \mathrm{mm}^{2}$ となっているが, この值は鉄筋コンクリートの場合と比較して著しく小さく規定され ている。これは, ALC パネルが設計荷重時に曲げひび割れを生じさ せないことを前提としているためであるが，上述のとおり，ALC パ ネル内の補強筋に内部応力として引張応力が作用していることを考 慮に入れると, このような観点からも補強筋の許容応力度が鉄筋コ ンクリートの場合より小さく設定されているのは妥当であると考え られる。

\section{2 ALC パネル表面のひずみ}

図 3 に ALC パネル表面の ALC ひずみ測定結果を示す。なお，図 2 と同様に, 図中には測定された值の範囲を縦線, 平均値をつで示 してある。主筋ひずみの場合と同様にばらつきがあるものの，ゲー ジ近傍の主筋を切断するように ALC パネルに切り込みを入れるこ とによって，ALC パネル表面には引張ひずみが測定された。主筋に 引張応力が存在し, その主筋が ALC を拘束することで ALC パネル に潜在的に圧縮応力が作用していることがわかる。No.4，5，6に ついては，横筋近傍で主筋を切断した際のひずみも測定したが（図 3(a)), 変化はほとんどなかった。横筋による拘束よりも, ALC と 主筋との付着の影響の方が大きいためであると判断できる。

ゲージ近傍切断時における ALC のひずみ測定結果（図 3(b)）に 関しては，同一母材で配筋量および補強筋径が異なる No.1，2，3 について比較した場合, 配筋量が多くなると, そして, 補強筋径が 大きくなると引張ひずみが $110 \times 10^{-6}$ 程度大きくなっている。また, 配筋量および補強筋径が同じで，母材が異なる No.1，4，5 を比較 すると, $100 \times 10^{-6}$ 程度のひずみ差であった。なお, 補強筋径が $5 \mathrm{~mm}$ で配筋量が 3 本の No.1，4，5 と，4 本の No.6 を比較した場合， No.6 は，No.5 より引張ひずみが小さいものの，No.1，4よりは大 きい。しかし，そのひずみ差は $100 \times 10^{-6}$ 程度の範囲であった。

ALC パネル表面の引張ひずみは配筋量が多くなると, また補強筋 径が大きくなると大きくなるが，母材である ALC の違いによる影 響は小さいと思われる。なお, ALC パネル表面の引張ひずみは 150 $\times 10^{-6} \sim 400 \times 10^{-6}$ の範囲であった。

本研究では，パネルの片面（引張側）のみのひずみ計測ではある が，上述のとおり配筋量が多くなると，また，補強筋径が大きくな ると $\mathrm{ALC}$ パネル表面の引張ひずみが大きくなった。ALC パネルは, 本来, 圧縮側と引張側では配筋量が異なるが, 両側の配筋が著しく 異なった場合, ALC パネルの圧縮側, 引張側で, その表面に作用寸 る応力も大きく異なることが考えられる。そのような場合, ALC パ ネルの反りの原因となることが想定される。このような現象は, 屋 根用や床用などのパネル長さが比較的短い場合は起こりにくいが, 壁用パネルなど，パネル長さが比較的長い場合には起こりやすいと 思われる。このように, ALC パネルの内部応力による影響を考慮す ると, 圧縮側と引張側の鉄筋比を一定以上にするなどの措置が必要 であると考えられる。

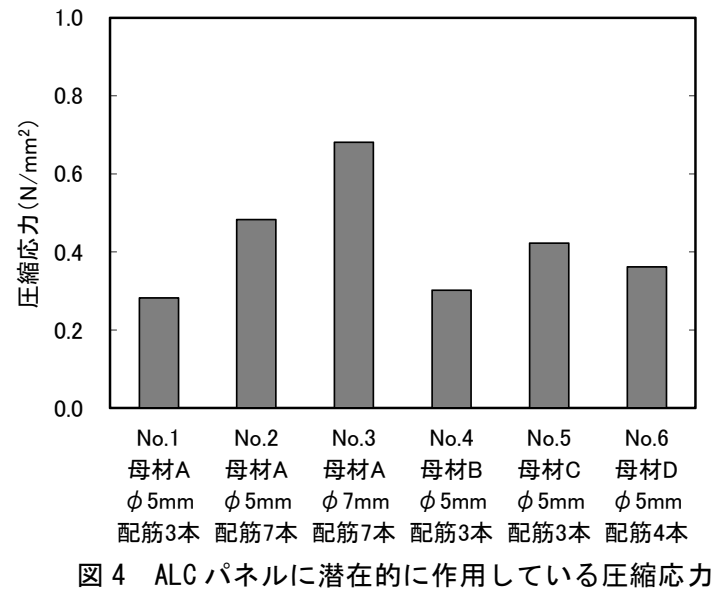

\section{3 ALC パネルに作用している内部応力}

前述より, ALC パネル内の主筋には引張応力が作用しており, そ の主筋の拘束により, ALC パネルには内部応力が働いていることが 明らかとなった。そこで，ALC のヤング係数を $1750 \mathrm{~N} / \mathrm{mm}^{2}$ とした 場合の ${ }^{1), 4)}$, ALC パネル表面の ALC ひずみから算出した ALC パネ ルに働いている圧縮応力を図 4 に示寸。これから, 配筋量, 補強筋 径，母材などの条件により差はあるものの，ALC パネルには 0.3 $0.7 \mathrm{~N} / \mathrm{mm}^{2}$ 程度の内部応力が発生していると考えられる。

\section{4. まとめ}

本研究の範囲内で，以下のことが明らかとなった。

（1）ALC パネル切断により，主筋には圧縮ひずみが発生し，そのひ ずみは配筋量が多くなると，また，補強筋径が大きくなると小 さくなる。

（2） ALC パネル切断により, ALC パネル表面には引張ひずみが発生 し，そのひずみは配筋量が多くなると，また，補強筋径が大き くなると大きくなる。

(3) ALC パネル内の主筋には引張応力, ALC パネル表面には圧縮応 力が作用しており, ALC パネルには圧縮方向の内部応力が存在 している。

（4） ALC パネルに存在している内部応力は，条件により異なるが， 概ね $0.3 \sim 0.7 \mathrm{~N} / \mathrm{mm}^{2}$ 程度である。

\section{謝辞}

本研究を実施するにあたり，旭化成建材（株），クリオン（株）に 多大なるご協力をいただきました。記して謝意を表します。

\section{参考文献}

1) 日本建築学会：建築工事標準仕様書・同解説 JASS21 ALC パネル, 2005.10

2）松沢晃一, 水谷吉克, 橘高義典, 進藤美慧 : タイル仕上げ ALC パネルの 曲げ性状に及ぼす張付け材およびタイル寸法の影響, 日本建築学会構造 系論文集，No.696，pp.209-217，2014.2

3）松村晃：オートクレーブ養生軽量気泡コンクリート（ALC）部材の基本 的曲げ強度性状 オートクレーブ養生気泡コンクリート部材の強度性状 の研究 その 1 , 日本建築学会論文報告集, No.336, pp.42-52, 1984.2

4）ALC 協会：ALC パネル構造設計指針・同解説， 2013.12

[2014 年 10 月 14 日原稿受理 2014 年 12 月 6 日採用決定］ 